Article

\title{
Post-Eruption Deformation Processes Measured Using ALOS-1 and UAVSAR InSAR at Pacaya Volcano, Guatemala
}

\author{
Lauren N. Schaefer ${ }^{1, *}$, Zhong $\mathrm{Lu}^{2}$ and Thomas Oommen ${ }^{1}$ \\ Received: 13 October 2015; Accepted: 8 January 2016; Published: 19 January 2016 \\ Academic Editors: Norman Kerle and Prasad S. Thenkabail \\ 1 Department of Geological and Mining Engineering and Sciences, Michigan Technological University, \\ Houghton, MI 49931, USA; toommen@mtu.edu \\ 2 Roy M. Huffington Department of Earth Sciences, Southern Methodist University, Dallas, TX 75205, USA; \\ zhonglu@mail.smu.edu \\ * Correspondence: Inschaef@mtu.edu; Tel.: +1-847-902-0422
}

\begin{abstract}
Pacaya volcano is a persistently active basaltic cone complex located in the Central American Volcanic Arc in Guatemala. In May of 2010, violent Volcanic Explosivity Index-3 (VEI-3) eruptions caused significant topographic changes to the edifice, including a linear collapse feature $600 \mathrm{~m}$ long originating from the summit, the dispersion of $\sim 20 \mathrm{~cm}$ of tephra and ash on the cone, the emplacement of a $5.4 \mathrm{~km}$ long lava flow, and $\sim 3 \mathrm{~m}$ of co-eruptive movement of the southwest flank. For this study, Interferometric Synthetic Aperture Radar (InSAR) images (interferograms) processed from both spaceborne Advanced Land Observing Satellite-1 (ALOS-1) and aerial Uninhabited Aerial Vehicle Synthetic Aperture Radar (UAVSAR) data acquired between 31 May 2010 and 10 April 2014 were used to measure post-eruptive deformation events. Interferograms suggest three distinct deformation processes after the May 2010 eruptions, including: (1) subsidence of the area involved in the co-eruptive slope movement; (2) localized deformation near the summit; and (3) emplacement and subsequent subsidence of about a $5.4 \mathrm{~km}$ lava flow. The detection of several different geophysical signals emphasizes the utility of measuring volcanic deformation using remote sensing techniques with broad spatial coverage. Additionally, the high spatial resolution of UAVSAR has proven to be an excellent compliment to satellite data, particularly for constraining motion components. Measuring the rapid initiation and cessation of flank instability, followed by stabilization and subsequent influence on eruptive features, provides a rare glimpse into volcanic slope stability processes. Observing these and other deformation events contributes both to hazard assessment at Pacaya and to the study of the stability of stratovolcanoes.
\end{abstract}

Keywords: volcano deformation; interferometric synthetic aperture radar; ALOS-1; UAVSAR

\section{Introduction}

The analysis of ground deformation at volcanoes has long been considered a crucial monitoring technique. Although geodetic systems such as Global Positioning Systems (GPS) can be used to determine ground motion, the logistical challenges of field monitoring-including high costs and the vulnerability of monitoring equipment near active volcanic vents-have rendered remote sensing a valuable addition for monitoring volcanic deformation. Interferometric Synthetic Aperture Radar (InSAR), in which the differences in phase of two or more temporally spaced synthetic aperture radar (SAR) images are used to determine surface deformation, has become a highly desirable measure of centimeter-scale deformation over large areas. This has allowed scientists to make measurements of volcanic deformation at otherwise unmonitored, or unexpectedly deforming, volcanoes (e.g., [1-5]). 
Using InSAR, much work has been devoted to connecting volcanic eruptions with geodetic signatures for eruption forecasting [6]. This has led to several inferences about the characteristics of magmatic plumbing systems and reservoirs (e.g., [5,7-12]). Some volcanoes have been known to show no deformation prior to eruption, while others deform without erupting, or exhibit deformation unrelated to magmatic intrusions, suggesting complex relationships between eruption behavior and resulting deformation (e.g., $[13,14])$. Here, we use satellite and aerial radar images to measure surface displacements following explosive eruptions in May 2010 at Pacaya volcano in Guatemala. L-band (wavelength $=23.6 \mathrm{~cm}$ ) Advanced Land Observing Satellite-1 (ALOS-1) satellite imagery, available from 2008 to 2011, is compared to and supplemented with L-band (wavelength $=23.8 \mathrm{~cm}$ ) Uninhabited Aerial Vehicle Synthetic Aperture Radar (UAVSAR) aerial data, available since 2011.

UAVSAR is a miniaturized polarimetric synthetic aperture radar (SAR) system designed for repeat pass deformation measurements on aerial platforms. Unique from typical Uninhabited Aerial Vehicle (UAV) sensors, which are unmanned platforms, the UAVSAR radar pod is mounted beneath a Gulfstream-III plane and flown by pilots over a specific path requested by NASA-approved researchers. While the radar is collecting data, on-board operators use Platform Precision Autopilot (PPA) to control the plane so it can fly the same flight path within a $10 \mathrm{~m}$ diameter tube for hundreds of kilometers at a time [15]. This is important to scientists who want to track changes on the surface of the earth from one flight to the next to study features like glaciers, earthquakes, volcanoes, and landslides using repeat-pass InSAR. The L-band radar onboard the UAVSAR operates at a central frequency of 1217.5 MHz to $1297.5 \mathrm{MHz}$, with a bandwidth of $80 \mathrm{MHz}$. The nominal flight altitude for UAVSAR is $12,500 \mathrm{~m}$, and the typical image swath width is $>23 \mathrm{~km}$. The spatial resolution of the resulting UAVSAR single-look-complex (SLC) imagery are $\sim 1.7 \mathrm{~m}$ in range and $\sim 0.8 \mathrm{~m}$ in azimuth. More information on flight planning and operations is available on the UAVSAR website (http://uavsar.jpl.nasa.gov/). We discuss the utility of this precise topography change monitoring technique for volcanic activity and use it to augment standard satellite techniques.

\section{Background}

Pacaya volcano, located in the Central American Volcanic Arc (CAVA) (Figure 1a) is a several thousand year old basaltic complex that has experienced eruptive episodes typically lasting a few centuries, with repose intervals of similar length [16,17]. One notable event was a large $\left(0.6-0.8 \mathrm{~km}^{3}\right)$ sector collapse that occurred between 600 and 1500 years ago [18,19], the collapse scarp of which is still visible today (Figure 1b). The current eruptive episode began in 1961, with interspersed Strombolian eruptions, ash plumes, and effusive lava flows depositing material primarily on the west and southwest flank within the collapse scarp [20]. The majority of lava flows and explosive activity originates from the summit of the active cone; however, many of the high-volume lava flows tend to erupt from vents lower on the volcano's flanks [21].

Using ALOS-1 data from 2007 to early 2010, an InSAR survey of the CAVA found no deformation faster than $27 \mathrm{~mm}$ /year that could be attributed to magmatic processes at any of the 20 historically active volcanoes [14]. At Pacaya, this was attributed to a high proportion of basalt ascending directly from the base of the crust without a period of crustal storage [14]. An InSAR investigation into explosive eruptions rated as VEI-3 eruptions on the Volcanic Explosivity Index (VEI) on the 27 and 28 of May 2010 found that the southwest flank of the edifice moved $\sim 3 \mathrm{~m}$ to the southwest during this two-day eruption [22]. This flank displacement, combined with historic collapse, confirms that slope instability is a serious threat at Pacaya. 
(a)

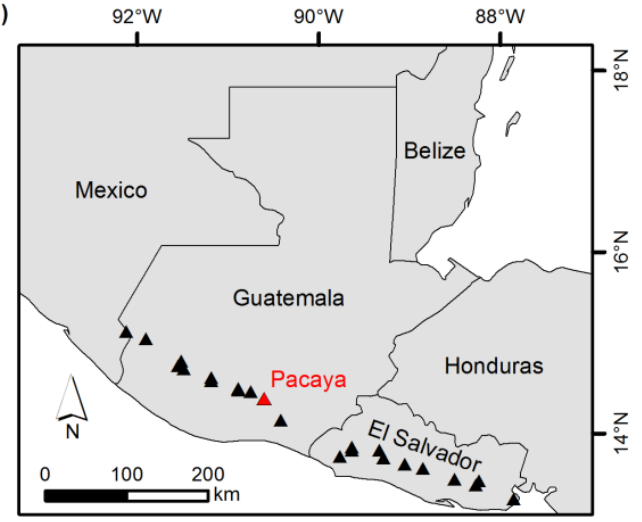

(b)

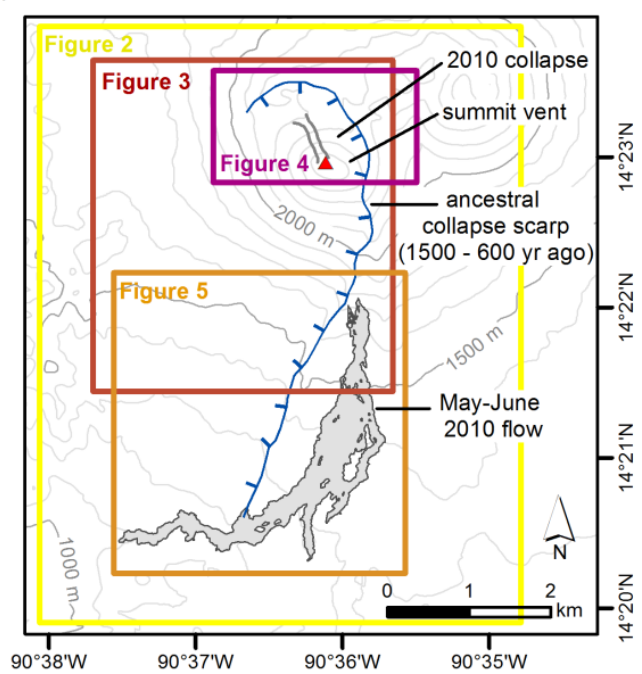

Figure 1. Location and major topographical features of Pacaya Volcano. (a) Pacaya volcano (red triangle) is located in the Central American Volcanic Arc (CAVA), with other CAVA volcanoes marked with black triangles; (b) Map showing the location of topographic features, including the summit vent, ancestral collapse scarp, and the linear collapse and lava flow as a result of the May 2010 eruptions. The colored boxes show the extent of Figures 2-5.

In addition to the slope movement, eruptive activity during the May 2010 eruptions produced several topographic changes to the edifice. On 27 May, about a $600 \mathrm{~m}$ long linear collapse initiated at the summit vent oriented NNW (Figure 1b), the origin of which is still debated [23]. On 28 May, a large lava flow erupted from 12 clustered vents to the SE of the summit around $1800 \mathrm{~m}$ above sea level (asl), being the first historic lava flow to originate outside of the collapse scarp (Figure 1b; [20]). According to reports by the National Coordinator for Disaster Reduction [24], the flow originally moved at a rate of $100 \mathrm{~m} / \mathrm{h}$. The flow rate slowed in the following days to $15 \mathrm{~m} / \mathrm{h}$ by 6 June and $1 \mathrm{~m} / \mathrm{h}$ by 8 June, until ceasing on 30 June. This is one of the largest lava flows that has erupted in the last 55 years, which flowed to the south for $\sim 3 \mathrm{~km}$ before curving west around $1300 \mathrm{~m}$ asl, following the local gradient. Ultimately, the flow reached $\sim 5.4 \mathrm{~km}$ in length, covering an area of $1.6 \times 10^{6} \mathrm{~m}^{2}$. Thickness estimates of 1-4 $\mathrm{m}$ result in a volume range of $1.6-6.4 \times 10^{6} \mathrm{~m}^{3}$ [20]. With continual eruptive activity and evidence of slope instability, it is imperative to monitor deformation events at Pacaya volcano.

\section{Radar Intensity Images}

The intensity of each pixel in a single radar image represents the proportion of microwave backscattered from that area on the ground, giving information of the type, shape, roughness, orientation, and moisture content of the target area. At Pacaya, radar intensity images can be used 
to discern features such as the summit crater area, 2010 collapse, ancestral scarp, and 2010 lava flow (Figure 2). The 2010 lava flow appears brighter than its surroundings due to its rough surface and its emplacement on the vegetated slope outside of the ancestral collapse scarp, which has different backscattering properties. The southern part of the lava flow becomes more difficult to distinguish as it moves into the lava flow fields within the ancestral scarp, suggesting that past and current flows have similar roughness (Figure 2b). The different orientations of the sloping walls of the 2010 collapse and ancestral collapse scarp make these features easily distinguishable. Additionally, the change in crater size can be seen after the eruption, which increases nearly six times to $\sim 600 \mathrm{~m}$ in diameter (Figure 2b). Single SAR images from the ALOS-1 satellite are very noisy due to speckle, a phenomenon in which the resolution of the SAR sensor is not sufficient to resolve individual scatterers. This speckle noise can often be reduced by averaging several SAR images. However, it is clear by comparing the averaged ALOS-1 scene (Figure 2c) to the UAVSAR images (Figure 2a,b) that a satellite sensor with a finer resolution is more desirable for distinguishing geological features (pixel size of $\sim 0.6 \mathrm{~m}$ in azimuth and $\sim 2.2 \mathrm{~m}$ in ground range for the original UAVSAR imagery, $v s . \sim 3.2 \mathrm{~m}$ in azimuth and $\sim 6.5 \mathrm{~m}$ in ground range for ALOS-1 SLC imagery over Pacaya volcano).

(a) UAVSAR: 2010/02/11

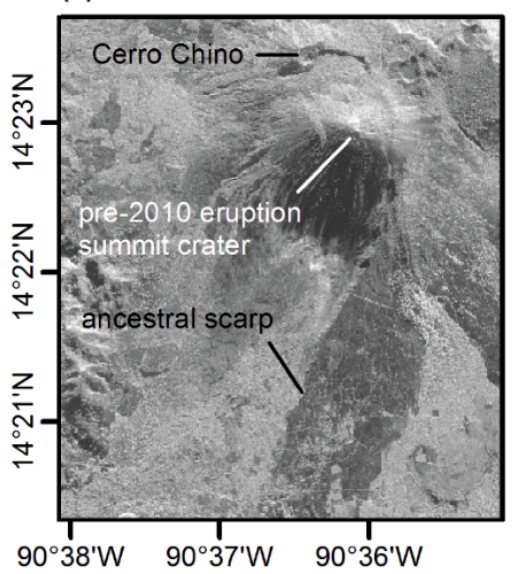

\section{(b) UAVSAR: 2011/04/26}

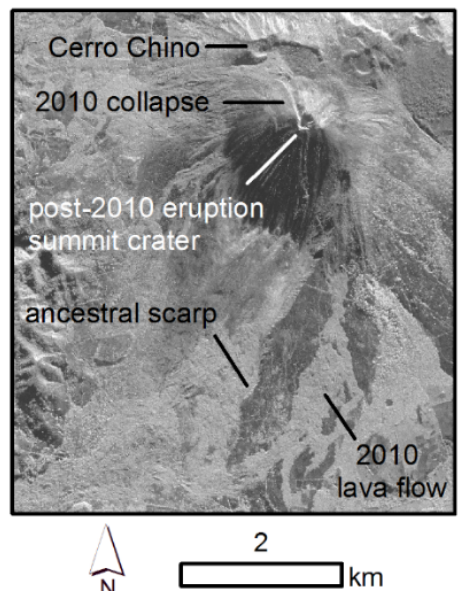

(c) ALOS-1: 2010/03/29 - 2011/02/14

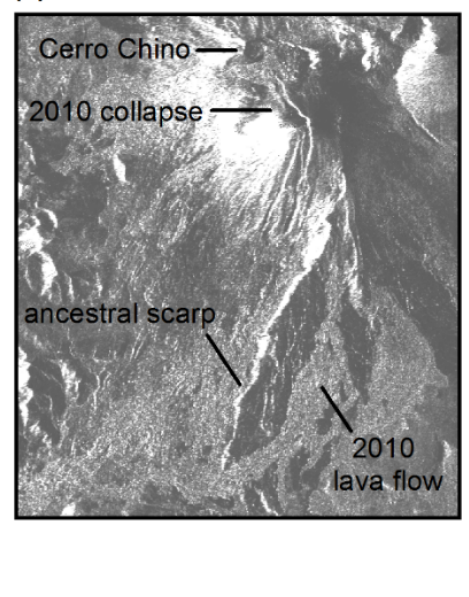

Figure 2. UAVSAR amplitude images of Pacaya volcano (a) before and (b) after the May 2010 eruptions clearly show changes to the edifice as a result of the eruption, including the emplacement of the $5.4 \mathrm{~km}$ long lava flow, an increase in the summit crater size, and the linear collapse oriented NNW from the summit; Panel (c) is an averaged image produced from eight ALOS-1 acquisitions between 2010 and 2011.

\section{InSAR Observations}

Using the two-pass InSAR approach (e.g., [25,26]), six interferograms of reasonably good coherence (where $50 \%$ of the study area maintains coherence larger than 0.3 in the unfiltered interferograms) were produced from satellite-based ALOS-1 SAR scenes from May 2010 to April 2011 (Table 1). NASA's Shuttle Radar Topography Mission (SRTM) 1-arc-second global digital elevation model (DEM) was used to correct for topography, which was interpolated and re-sampled to a spacing of $\sim 6 \mathrm{~m}$. Additionally, four interferograms from 2010 to 2014 were analyzed from aerial UAVSAR, processed by the NASA Jet Propulsion Laboratory (JPL) but cropped to Pacaya's extent for this study. Interferograms were filtered and unwrapped using minimum cost flow and triangulation [27]. However, all interferograms are shown as wrapped phase, in which each fringe or color cycle (e.g., magenta-magenta), represents $11.8 \mathrm{~cm}$ or $11.9 \mathrm{~cm}$ of displacement in ALOS-1 and UAVSAR interferograms, respectively. Deformation measurements are assumed to be primarily vertical (see justification later), calculated using geometric relations between the incident angle of the radar to the surface (reported in Table 1), and the line-of-sight (LOS) displacement, or direction between 
the SAR antenna and the point on the ground surface. UAVSAR images have nearly the opposite LOS direction from ALOS-1 images (Table 1). Fringe patterns were compared to other interferograms with larger baselines to discard any topography-related errors. As perpendicular baselines of interferograms used in this study are less than $341 \mathrm{~m}$ (Table 1), the altitude of ambiguity [25] is larger than $190 \mathrm{~m}$. Hence, topography-induced errors in these interferograms can be neglected. Currently, no advanced analysis of GPS data is available for comparing the deformation measured here [22].

Table 1. Interferogram pairs used in this study.

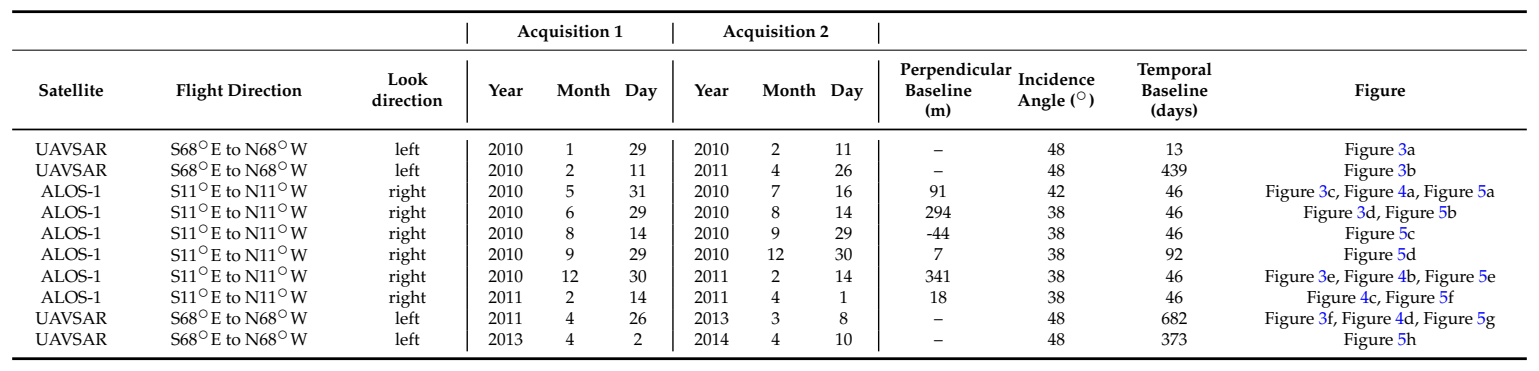

After the co-eruptive slope movement of the southwest flank on 27 May and 28 May (Figure 3b), flank-wide subsidence appeared in the first SAR image acquired on 31 May 2010, three days after the eruptions. This deformation is not seen in ALOS-1 interferograms before the eruptions (Figure 3a). The spatial extent of deformation is very similar to the original slope movement, marked with a dashed line in Figure 3a-f. Additionally, the pattern is similar between ALOS-1 (Figure 3c) and UAVSAR (Figure 3f) interferograms, which have nearly opposite looking geometries. This suggests that the deformation observed after the slide was likely dominated by vertical subsidence. The greatest magnitude of subsidence, $\sim 18 \mathrm{~cm}$, occurs near the summit, which reduces along the slope to $\sim 2 \mathrm{~cm}$ at the toe of the slide. These values subsequently decrease in magnitude and area through early 2011 (Figure 3d,e). A UAVSAR interferogram that spans 26 April 2011-8 March 2013, shown with magnified fringe values in Figure 3f, shows that this area was still subsiding at slow rates at least into the spring 2011.

In addition to the subsidence of the southwest flank, a localized deformation event on the cone appears after the May 2010 eruptions (Figure 4). This feature, elongated NW-SE, appears north of the summit and was contained mostly within the ancestral collapse scarp except for a portion to the east. These fringes are difficult to differentiate from the flank subsidence in the ALOS-1 interferograms immediately post-eruption (Figure 4a) but become clearer in subsequent months as flank subsidence diminishes (Figure $4 \mathrm{~b}, \mathrm{c}$ ). Interferograms measure a maximum of $\sim 25 \mathrm{~cm}$ of deflation between 31 May 2010 and 16 July 2010 (Figure 4a), which reduces in magnitude to $10 \mathrm{~cm}$ over 682 days between 2011-2013 (Figure 4d). This subsidence differs in magnitude from that measured on the flank, and continues well beyond post-slide settlement, emphasizing a separate source. Several lava flows were deposited to the north of the summit, with selected flows shown in Figure $4 \mathrm{e}$, which cover some of the spatial extent of the deformation described. 
(a) UAVSAR: $2010 / 01 / 29$ - 2010/02/11

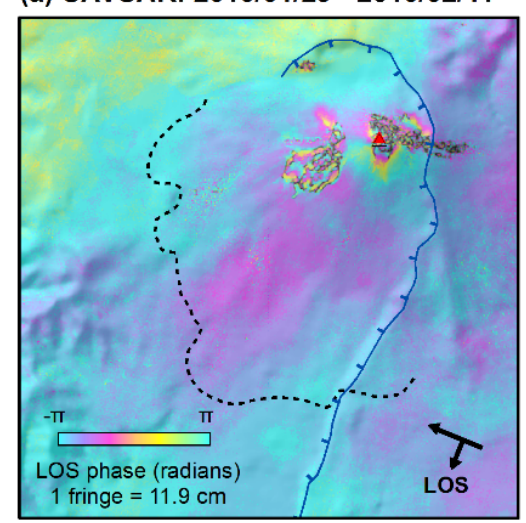

(c) ALOS-1: 2010/05/31 - 2010/07/16

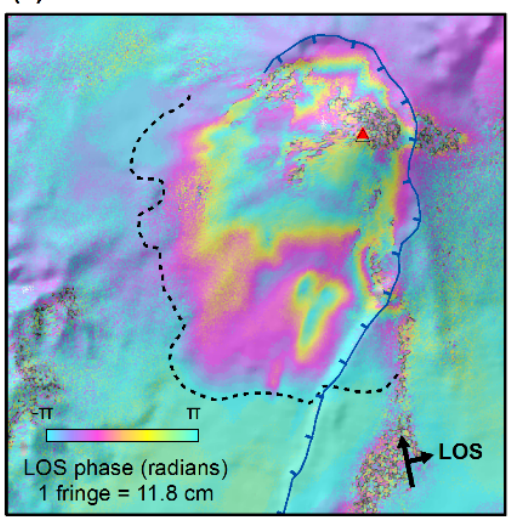

(e) ALOS-1: 2010/12/30 - 2011/02/14

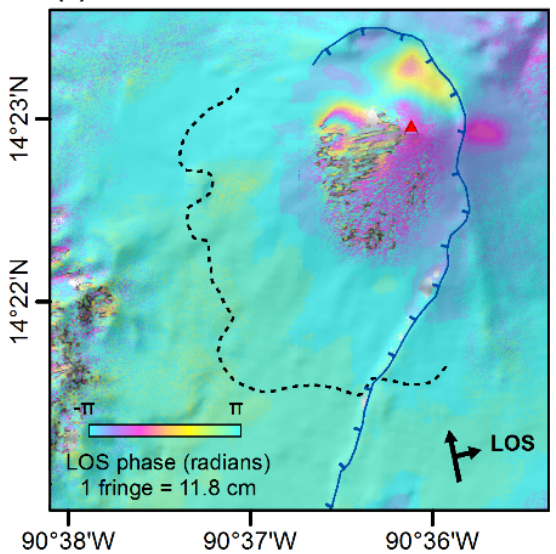

(b) UAVSAR: 2010/02/11 - 2011/04/26

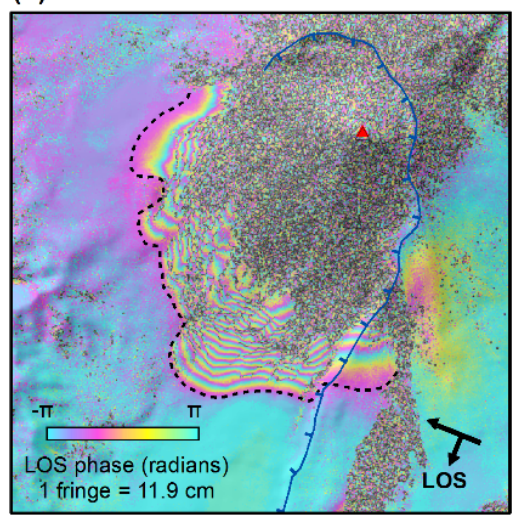

(d) ALOS-1: 2010/06/29 - 2010/08/14

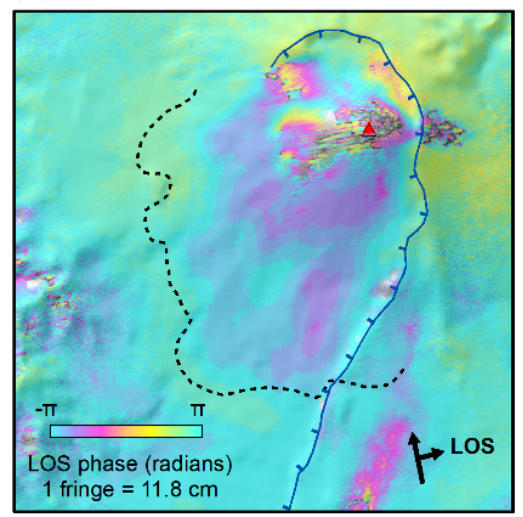

(f) UAVSAR: 2011/04/26 - 2013/03/08

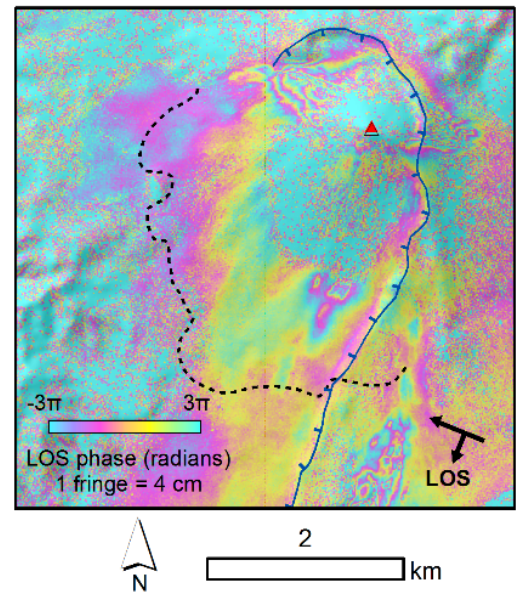

Figure 3. Slope deformation surrounding the May 2010 eruptions, with the black dashed line marking the outline of the slope instability in panel 3b. (a) No deformation of the southwest slope is seen prior to the eruption; (b) During the eruptions on the 27 and 28 of May, $3 \mathrm{~m}$ of LOS slope displacement can be seen on the southwest sector of the edifice (modified from [22]); (c) Immediately after the eruption, subsidence encompasses a similar extent of the southwest flank that moved during the slide; (d,e) This deformation decreases in magnitude and spatial extent until late December; (f) Deformation measured using the first available UAVSAR data after the May 2010 eruption spanning 26 April 2011-8 March 2013 is magnified to show the similarities in the fringe pattern over the southwest flank of the volcano. Similar fringe patterns between this UAVSAR interferogram and the ALOS- 1 interferogram in Figure 3c suggests that the deformation observed after the slide is likely dominated by vertical subsidence, as the sensors have nearly opposite looking geometries. 
(a) ALOS-1: 2010/05/31 - 2010/07/16

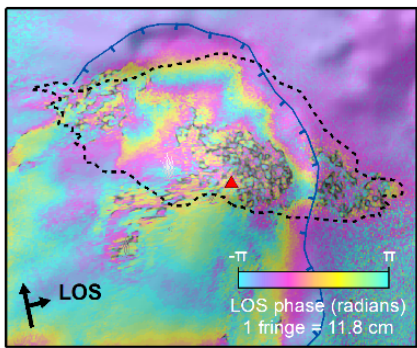

(c) ALOS-1: 2011/02/14 - 2011/04/01
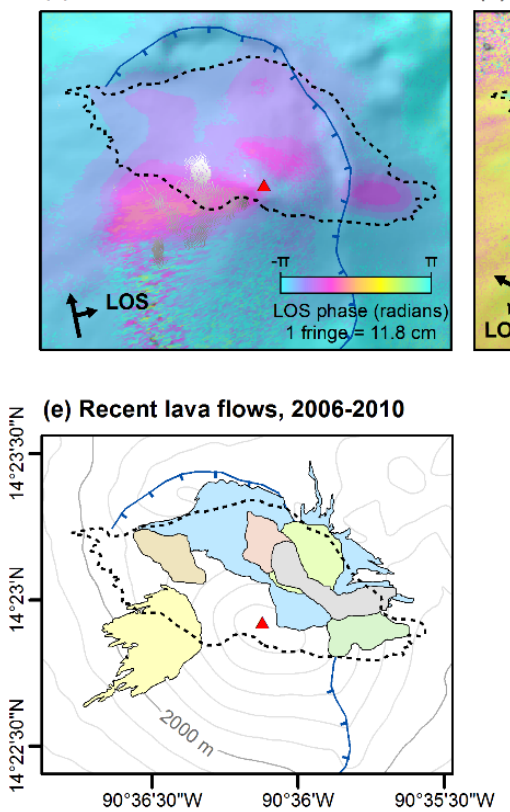

(b) ALOS-1: 2010/12/30 - 2011/02/14

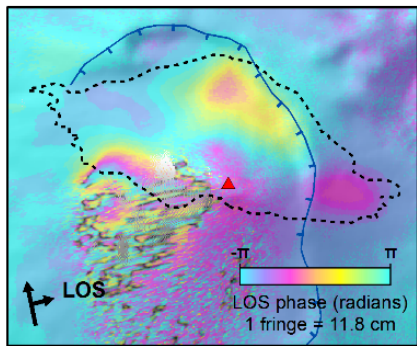

(d) UAVSAR: 2011/04/26 - 2013/03/08

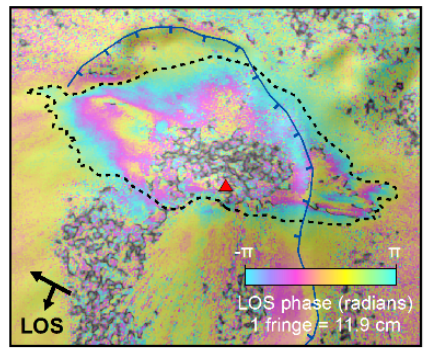

4. summit vent

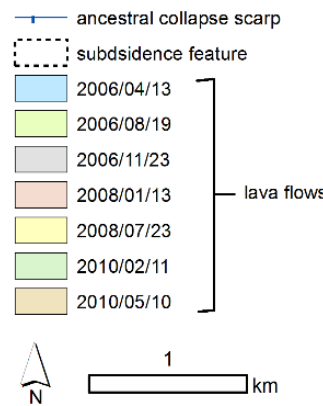

Figure 4. Localized deformation to the north of the summit. (a) Several fringes to the north of the summit are difficult to discern from subsidence of the southwest flank in the ALOS-1 interferogram immediately after the eruptions on 27 and 28 May; $(\mathbf{b}, \mathbf{c})$ This signal becomes the only deformation event in subsequent months, reducing in magnitude and spatial extent; (d) Fringes are more distinct in a later UAVSAR interferogram, which shows that the area was still subsiding at very slow rates $(\sim 10 \mathrm{~cm}$ over 682 days) between 2011 and 2013; (e) Several recent lava flows (outlined from Landsat satellite images and [20]) have flowed to the north of the summit, the contraction of which could account for some of the measured deformation.

A final discernible deformation process is shown in eight interferograms in Figure 5, which depict the emplacement (Figure 5a) and subsequent subsidence (Figure 5b-h) of the 2010 lava flow (outlined in Figure 1b). The interferogram covering the time interval immediately after the eruption (31 May-16 July) additionally contains several ovoid fringes of inflation oriented NNW-SSE near the 2010 lava flow vents (zoomed view, Figure 5a). The fringes, which represent $\sim 16 \mathrm{~cm}$ of LOS range shortening (corresponding to inflation if the deformation is assumed vertical), extend from the SE slope over the ancestral collapse scarp around 1700-1900 m asl. This area of inflation is directly related to lava flow emplacement, as they are not seen in ALOS-1 interferograms prior to (Figure 3a) or after (Figure 3d) the effusive eruption. The elongated shape suggests a diking event forced magma to the surface, resulting in inflation near the vents.

Much of the lava flow becomes coherent in July (Figure 5b), which agrees with CONRED reports of emplacement that state that the flow began on 28 May and ceased movement 33 days on 30 June. Thus, from July 2010 to April 2014, the lava flow shows persistent subsidence that varies in rate but 
decreases over time (Figure 6 and Table 2). The rate of subsidence is assumed to be constant over the time spanned by each interferometric pair, and the motion is presumed to be primarily vertical as the interferograms of opposite geometries (ALOS vs. UAVSAR) show essentially the same sense of motion. The deformation is contained within the boundaries of the flow and interferograms with smaller baselines in previous studies show no deformation in this area outside the scarp from 2007 to 2010 [22]. Thus, deformation can be directly related to subsidence of the lava flow. The area of maximum subsidence (cross section A-A', Figures $5 \mathrm{~d}$ and 6 ) is likely the thickest area of the flow [28]. This area corresponds with a decrease in the topographic gradient, which could cause lava pooling. The profiles of range change rate (Figure 6) also show that there are higher subsidence rates in the middle of the flow, which implies it is thicker in the center than at the edges. The difference in subsidence rates along the flow suggests that the thickness is not uniform. UAVSAR data shows that the lava flow was still subsiding in the thickest part between 2013 and 2014, several years after emplacement.

(a) $2010 / 05 / 31$ - 2010/07/16

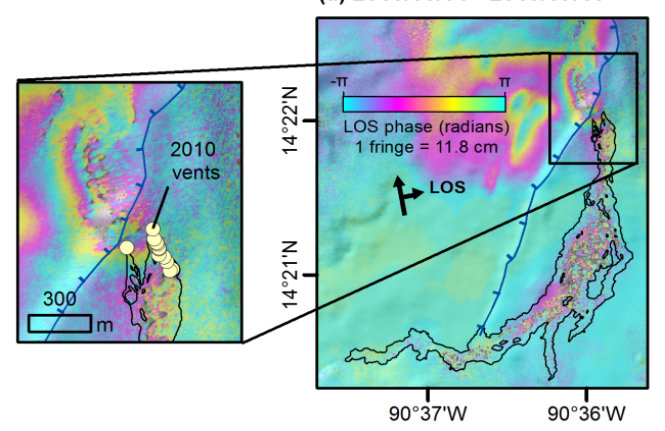

(c) $2010 / 08 / 14-2010 / 09 / 29$

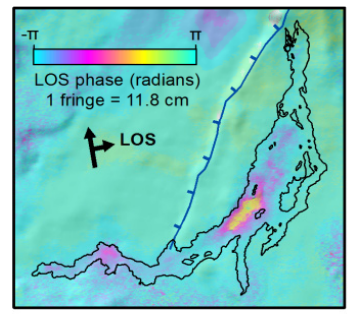

(f) $2011 / 02 / 14-2011 / 04 / 01$

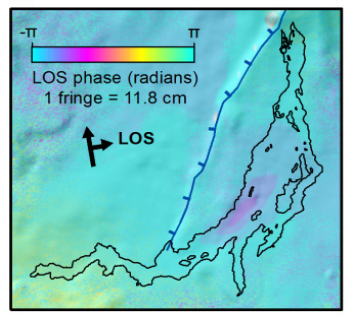

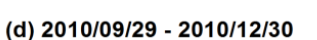

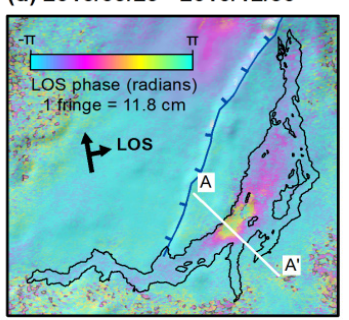

(g) $2011 / 04 / 26-2013 / 03 / 08$

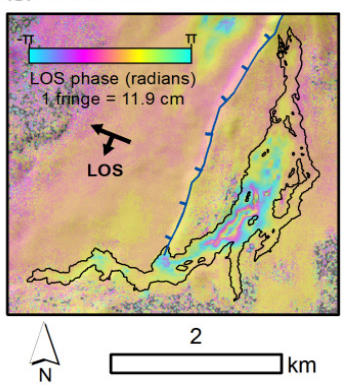

(b) 2010/06/29 - 2010/08/14

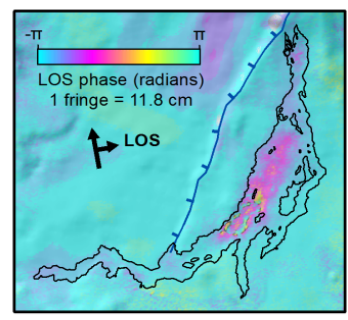

(e) $2010 / 12 / 30-2011 / 02 / 14$

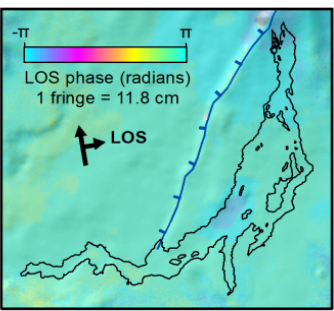

(h) 2013/04/02 - 2014/04/10

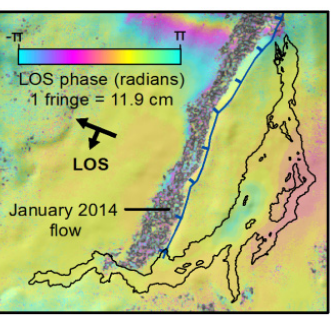

Figure 5. InSAR images showing post-emplacement surface movement of the lava flow that began on 28 May 2010, with the approximate extent of the lava flow outlined. (a) Emplacement of the flow continues until 30 June, and then subsides at a decreasing rate over time, shown in the following time frames: (b) 29 June 2010-14 August 2010; (c) 14 August 2010-29 September 2010; (d) 29 September 2010-30 December 2010; (e) 30 December 2010-14 February 2011; (f) 14 February 2011-1 April 2011; (g) 26 April 2011-8 March 2013; and (h) 2 April 2013-10 April 2014. Line A-A' in 5d crosses the approximate area of maximum subsidence, with values in Table 1 and a time series of profiles of range change rate deformation rates along this profile in Figure 6. 
Table 2. Maximum deformation rate (in $\mathrm{cm} /$ day) of the 2010 lava flow shows that the rate of subsidence, and thus rate of cooling, decreases over time. Loss of coherence due to emplacement does not allow measurements to be made until 78 days after the initiation of the flow.

\begin{tabular}{ccc}
\hline i.d. (see Figure 6) & $\begin{array}{c}\text { Cumulative Days Post } \\
\text { Emplacement }\end{array}$ & Maximum Deformation (cm/day) \\
\hline a & 49 & N/A \\
b & 78 & N/A \\
c & 124 & -0.11 \\
d & 216 & -0.06 \\
e & 262 & -0.02 \\
f & 308 & -0.02 \\
g & 1015 & -0.02 \\
h & 1413 & -0.006 \\
\hline
\end{tabular}

* end of time interval spanned by each interferogram; ${ }^{\dagger}$ start of emplacement: 28 May 2010.

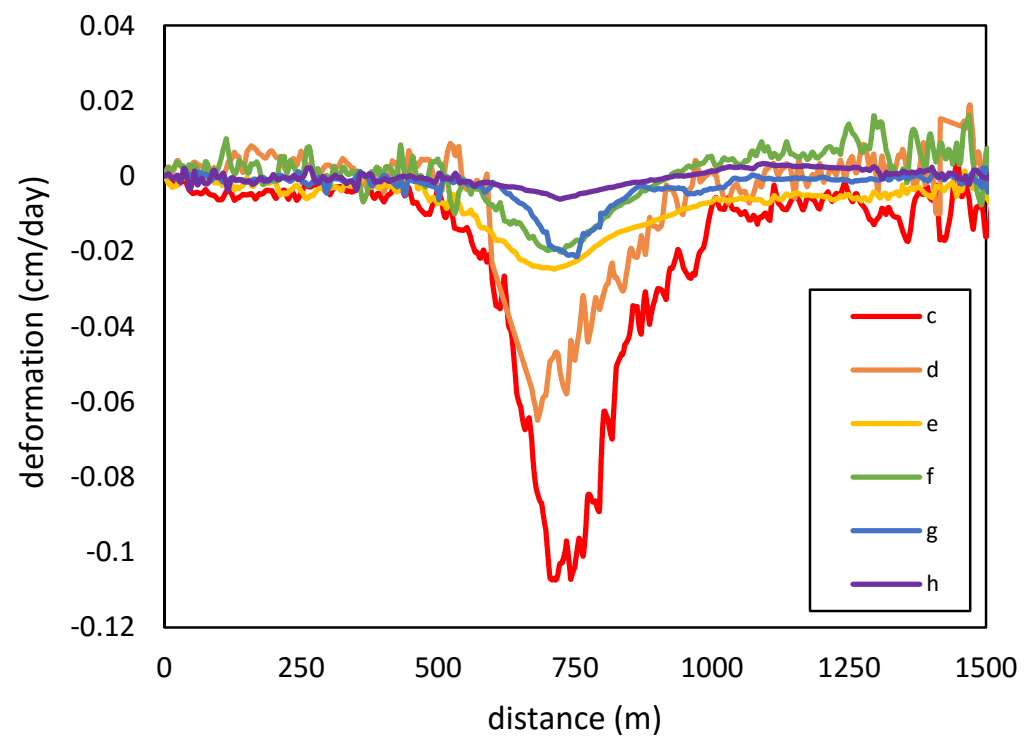

Figure 6. Deformation rate of cross section $A-A^{\prime}$ in Figure $5 d$ shows that lava flow subsidence is greatest in the center, which can be inferred to be the thickest part of the flow.

\section{Discussion}

Three distinct deformation processes have been measured after the 2010 eruption: subsidence of material involved in the co-eruptive landslide event, localized deformation near the summit, and emplacement and subsequent subsidence of the 2010 lava flow. These will be discussed in turn.

\subsection{Post-Sliding Flank Deformation}

Interferometric signals due to degassing or magma withdrawal are typically a broader, more symmetrical fringe pattern, indicative of a relatively deep source (i.e., the depth of the magma reservoir, e.g., [12]). This is not what we observe after the eruption; instead, the fringe patterns suggest that the source causing deformation is rather surficial (Figure 3c). Thus, we can discount degassing and/or magma withdrawal as the causes of the subsidence measured on the southwest flank. A lack of inflation prior to the eruption additionally suggests that either magma was transported directly from depth (i.e., [14,29]) or that it was already present in the shallow crust prior to the eruption. The latter has been suggested by several authors. Eggers [16] originally proposed that the petrographic and chemical uniformity of Pacaya's lavas through time implied a continuous supply of magma to an 
open conduit. This has been further proven by excessive degassing at the volcano [30-34], which implies that Pacaya has a substantial convecting and circulating magma body near the surface that is degassing but not erupting completely on the surface [21,33]. Additionally, gravity changes measured by Eggers [35] were accounted for by density changes caused by very shallow magma bodies (depths of 100 to $200 \mathrm{~m}$ below the surface).

The measured subsidence is confined to the southwest flank and covers the same extent of material involved in the co-eruptive sliding event. During the May 2010 eruptions, the majority of tephra was distributed to the north due to prevailing winds, as evidenced by coherence of the lower flanks of the edifice in the interferogram that spans the eruption (Figure 3b). This confirms that erupted material did not reach some areas of post-eruption subsidence, making it unlikely that measured subsidence on the southwest flank is due to thermal contraction of hot erupted material alone (i.e., [36]). This subsidence continues for several months, however it decreases in rate and becomes confined to the upper flanks of the cone (Figure 3d,e). Therefore, it is likely due to mechanical clast repacking in response to co-eruptive displacement as material stabilizes and consolidates, with higher levels of repacking corresponding to areas of greater levels of prior slope displacement. However, we cannot discount some component of thermoelastic contraction on the upper flanks due to cooling of erupted material.

Pre- and post-eruptive interferograms reveal that flank instability is confined to the May eruptions [22]. This is unique from other measurements of volcanic flank movement, which have typically been attributed to relatively slow (10 cm or less) and steady (up to tens of years) gravitational creep (i.e., [37] and references therein). Instead, movement seems to both initiate and cease rapidly, followed by dominantly vertical subsidence as the slope stabilizes. The lack of gravitational instability fits with numerical models of flank collapse at Pacaya, which show that the edifice is stable under gravity forces alone but could be destabilized by magmatic or seismic forces [23]. Thus, either the edifice load is not great enough to induce gravitational creep, or the failure plane is not well established. Instead, flank movement seems to be directly linked to overpressure associated with a magmatic intrusion (i.e., Piton de la Fournaise [29]). The spatial variability in subsidence rates probably relates to sliding movement heterogeneity. There is no obvious thrust feature at base of the southwest slope to accommodate the large motion, which is likely obscured due to the re-organization of the relatively fresh deposits in this area (the map of which is available in [20]).

\subsection{Localized Deflation}

Immediately after the eruption, fringes to the north of the summit appear to be a continuation of the material subsidence (Figure 4a), suggesting that this area may also have been involved in co-eruptive flank displacement (this information being lost in co-eruptive interferograms due to incoherence, [22]). In later interferograms, this signal becomes an elongated feature oriented NW-SE. In addition to becoming constrained to the upper flanks of the northern sector, it also has different subsidence rates from surrounding areas, including the southwest flank. Thus, we can consider this continuing subsidence feature as a distinct event from the initial southwest flank displacement as time progresses. Deformation appears as separate lobes which have different rates (Figure 4b,c), making it likely that these lobes reflect the subsidence of historic lava flows deposited to the north of the cone (Figure 4e). However, the complicated signal makes it difficult to discern specific flows or measure their compaction rates. An additional possibility is that this area is experiencing substrate compaction due to continued emplacement of lava and tephra [38]). Alternatively, continuing subsidence may indicate crystallization and cooling of newly intruded magma in the shallow sub-surface [10,39]).

\subsection{Lava Flow Emplacement and Subsidence}

The rate of subsidence on the 2010 flow varied both spatially and temporally, with the maximum subsidence rate initially at $\sim 0.1 \mathrm{~cm} /$ year after emplacement, reducing to $\sim 0.02 \mathrm{~cm} /$ year between 2013 and 2014. This subsidence rate is low compared to other measurements made using InSAR, such as the $10 \mathrm{~cm}$ of subsidence measured in 44 days at Okmok [28]. This is likely due to differences in lava 
flow thickness estimates; the Okmok flow is estimated to be $20 \mathrm{~m}$ thick [40], while the 2010 flow at Pacaya is estimated to be 1-4 m [20]. Incoherence within the flow boundaries of ALOS-1 interferogram immediately after the eruptions, spanning from 31 May through 16 July (Figure 5a), shows that the flow surface was changing enough to destroy coherence during the first $\sim 1.5$ months after emplacement, presumably as a result of the mechanical movement of unstable blocks. This fits field reports by CONRED, which state that the flow ceased on 30 June.

The thickest area of the flow becomes coherent 78 days after initiation (Figure $5 \mathrm{c}$ ), with the majority of the flow becoming coherent only 32 days after initiation (Figure 5b). Due to the temporal resolution of ALOS-1 data (46 days), these dates cannot be further constrained. However, this timeframe falls on the lower end of the range of other InSAR studies; Kìlauea flows reached coherence 13 to 903 days after emplacement [41], while Okmok flows reached full coherence $\sim 3$ years after emplacement [28]. At Pacaya, fast coherence rates are likely due to the fast emplacement and relative thinness (1-4 m) of the 2010 flow.

Post-emplacement lava flow deformation has been attributed to several processes, including thermal contraction and consolidation [42], substrate compaction [38], and clast repacking or gravity-driven compaction [43]. It is difficult to determine the exact cause of subsidence for the 2010 lava flow without more frequent temporal sampling of subsidence and temperature measurements, but the measured deformation is likely related to both thermal and mechanical processes shortly after the emplacement and then primarily cooling of lava flows afterwards. Given the full spatial coverage of the flow provided by InSAR, thickness estimates of the flow, which currently range from $1 \mathrm{~m}$ to $4 \mathrm{~m}$ [21], could be constrained (i.e., [43]), ultimately leading to remote monitoring of lava flow extrusion rates. Given the high effusive activity since 1961 [20], this could lead to knowledge of effusive eruption dynamics over time.

Mapping of discontinuities along the ancestral collapse scarp has shown that Pacaya is subjected to both an E-W extensional regime of the Guatemala City graben to the north and the NW-striking Jalpatagua shear zone, resulting in a transtensional local stress regime with an ENE-WSW $\sigma_{3}$ component [23]. Regional stress regimes have been known to favor vertical magma migration by propagation of dikes through pre-existing cracks or faults, which reduce overpressure [44]. This could help explain the dike intrusion elongated NNW-SSE (Figure 5a), which stretches over the ancestral collapse scarp following the edge of the slope displacement. This tells us that propagation of the dike was controlled by both the local transtensional stress regime and the reduction of overpressure as a result of southwest flank displacement. This also suggests that the topographic anomaly of the ancestral collapse scarp is not the primary mechanism controlling vent emplacement.

A NNW dike system is further evidenced by cracking along this theoretical weakness zone as seen after the May 2010 eruptions and continued emplacement of vents aligned in a NNW-orientation over time (Figure 7a). Thus, injection of magma along this orientation during the 2010 eruptions could have caused the force needed to induce the perpendicularly-oriented slope movement. The 2010 collapse could have been a result of either the intrusion or the slope movement. In 2014, lava flow vents continued to open along this trend to the NNW of the 2010 clustered vents (Figure 7a), resulting in the emplacement of a $4.3 \mathrm{~km}$-long lava flow (Figure $7 \mathrm{~b}$ ). As this system continues to "unzip," these intrusions and subsequent vent openings could facilitate future slope movement to the SW. Geomechanical studies have found that continued dike intrusions have the possibility of imparting mechanical damage to the rock [45], leading to edifice weakening and a higher probability of slope instability. Additionally, if several pathways bleed the main conduit, the lack of localized accumulation of degassed magma may not cause deformation measurable above InSAR detection limits until magma reaches the surface [46], such as the diking event near the 2010 vents (Figure 5a). This could account for a lack of measurable inflation due to magma intrusion into the cone prior to the 2010 eruptions (Figure 3a, [22]).

Eruptions of high-volume lava flows from lower flank vents is a recurring event at Pacaya (Figure 7b, [21]), which have been attributed to the existence of shallow magma stored in the cone [20]. 
High discharge effusion rates of these flank lava flows $\left(\sim 5 \mathrm{~m}^{3} / \mathrm{s}\right.$, [47]) suggest that a hydrostatic effect causes the upper portion of the conduit to drain (the steady supply rate of magma to the conduit being $\sim 0.09 \mathrm{~m}^{3} / \mathrm{s}$ ). Therefore, material that did not erupt through the summit vent in the May 2010 eruptions could have partially drained into the 2010 lava flow. Although a loss of coherence of the summit area prevents us from seeing any co-eruptive deflation related to this type of event (Figure 3b), it is likely that the high magnitude of flank displacement would overshadow this signal.
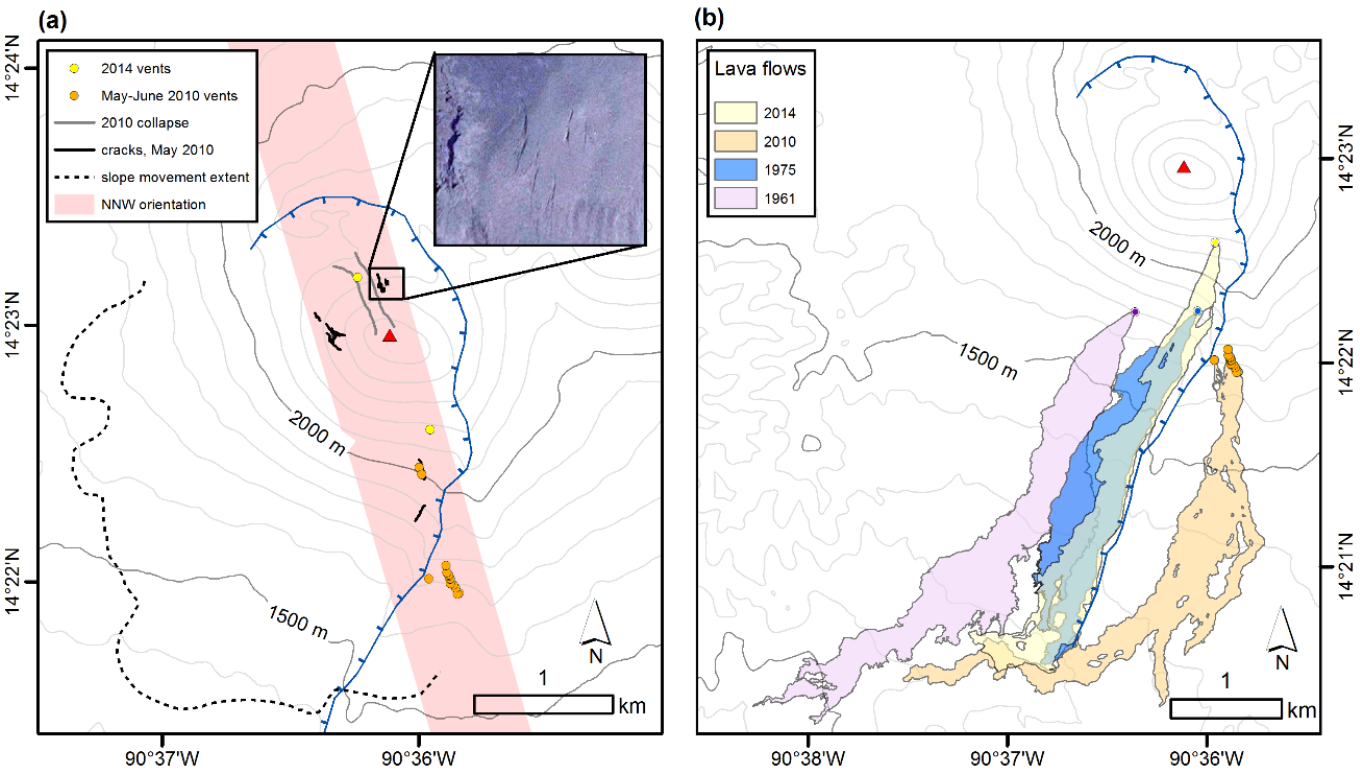

Figure 7. Eruptive trends at Pacaya. (a) A continued NNW-oriented pattern of vents and cracks is seen post-2010 eruption. Intrusions along this weakness zone could have provided the push to induce slope displacement during the May 2010 eruption. Cracks were mapped using Google Earth aerial images (inset image taken in December 2010, courtesy of Google 2015 DigitalGlobe); (b) High volume lava flows tend to erupt from lower flank vents such as in 1961, 1975, 2010, and 2014, suggesting a cyclical draining of a shallow magma system in the cone. Outlines for the 1961 and 1975 lava flows from [21].

\section{Conclusions}

InSAR has revealed several deformation events at Pacaya Volcano, Guatemala, after eruptions on the 27 and 28 of May 2010. Three meters of co-eruptive displacement of the southwest flank is followed by several months of material consolidation, giving a rare glimpse of flank stabilization processes. The rapid initiation and cessation of flank displacement is unique from other measurements of volcanic flank movement, which have typically been attributed to gravitational creep. Localized deformation near the summit likely reflects the subsidence of historic lava flows deposited to the north of the cone, although the complicated signal makes it difficult to discern specific flows. Alternatively, this feature may indicate slow crystallization and cooling of newly intruded magma, which implies a complex conduit system. Interferograms also reveal the emplacement and subsequent subsidence of a 5.4-km long lava flow, which is the first historic flow to erupt outside of the ancestral collapse scarp. We attribute its eruption location to both the local transtensional stress regime and the structurally weak zone as a result of southwest flank displacement. The recurrence of these high-volume lava flows erupting from flank vents additionally suggests a cyclical pattern of high-level magma systems draining into lower vents. The existence of shallow magma within the cone has serious implications for the already unstable volcano. This is particularly true given the repeated pattern of magma intrusion along a NNW-orientation, perpendicular to the flank displacement. The utility of InSAR for measuring the complex geophysical signals at Pacaya is evident given the variety of deformation measurements revealing both eruptive and non-eruptive behavior. In particular, the high spatial resolution of aerial 
UAVSAR has proven to be an excellent compliment to satellite data, particularly when it comes to constraining motion components. Although direct measurement comparisons between the two sensors is limited due to the lack of temporal overlap, future ALOS-2 missions could benefit from UAVSAR acquisitions. The deformation detected at Pacaya promotes the future use of InSAR at this and other potentially unstable volcanoes.

Acknowledgments: Lauren N. Schaefer acknowledges support provided by the NASA Earth and Space Science Fellowship Program (NNX13AO50H) and the AEG (Association of Environmental and Engineering Geologists) Foundation. Zhong Lu acknowledges support from the NASA Earth Surface and Interior Program (NNX14AQ95G) and the Shuler-Foscue Endowment at Southern Methodist University (Dallas, TX, USA). ALOS-1 (Advanced Land Observing Satellite) data were acquired from the Japan Aerospace Exploration Agency via the Alaska Satellite Facility through the WInSAR (Western North America Interferometric Synthetic Aperture Radar) Consortium, and were processed using Gamma software (http://www.gamma-rs.ch/). UAVSAR (Uninhabited Aerial Vehicle Synthetic Aperture Radar) interferograms were courtesy of the NASA Jet Propulsion Laboratory-California Institute of Technology. The authors wish to thank three anonymous reviewers for helping to improve this manuscript.

Author Contributions: Lauren N. Schaefer, Zhong Lu, and Thomas Oommen conceptualized the manuscript and provided revision throughout the study. Lauren N. Schaefer drafted the manuscript. Zhong Lu and Lauren N. Schaefer processed InSAR data.

Conflicts of Interest: The authors declare no conflict of interest.

\section{References}

1. Biggs, J.; Anthony, E.; Ebinger, C. Multiple inflation and deflation events at Kenyan volcanoes, East African Rift. Geology 2009, 37, 979-982. [CrossRef]

2. Lu, Z.; Wicks, C.; Dzurisin, D.; Power, J.A.; Moran, S.C.; Thatcher, W. Magmatic inflation at a dormant stratovolcano: 1996-1998 activity at Mount Peulik volcano, Alaska, revealed by satellite radar interferometry. J. Geophys. Res. B Solid Earth (1978-2012) 2002, 107. [CrossRef]

3. Amelung, F.; Jónsson, S.; Zebker, H.; Segall, P. Widespread uplift and "trapdoor"faulting on Galapagos volcanoes observed with radar interferometry. Nature 2000, 407, 993-996. [PubMed]

4. Wicks, C.W.; Dzurisin, D.; Ingebritsen, S.; Thatcher, W.; Lu, Z.; Iverson, J. Magmatic activity beneath the quiescent Three Sisters volcanic center, central Oregon Cascade Range, USA. Geophys. Res. Lett. 2002, 29. [CrossRef]

5. Pritchard, M.E.; Simons, M. A satellite geodetic survey of large-scale deformation of volcanic centres in the central Andes. Nature 2002, 418, 167-171. [CrossRef] [PubMed]

6. Segall, P. Volcano deformation and eruption forecasting. Geol. Soc. Lond. Spec. Publ. 2013, 380, 85-106. [CrossRef]

7. Massonnet, D.; Briole, P.; Arnaud, A. Deflation of Mount Etna monitored by spaceborne radar interferometry. Nature 1995, 375, 567-570. [CrossRef]

8. Wicks, C.; Thatcher, W.; Dzurisin, D. Migration of fluids beneath Yellowstone caldera inferred from satellite radar interferometry. Science 1998, 282, 458-462. [CrossRef] [PubMed]

9. Zebker, H.A.; Amelung, F; Jonsson, S. Remote sensing of volcano surface and internal processes using radar interferometry. In Remote Sensing of Active Volcanism; American Geophysical Union: Washington, DC, USA, 2013; pp. 179-205.

10. Lu, Z.; Dzurisin, D. InSAR imaging of Aleutian Volcanoes. In InSAR Imaging of Aleutian Volcanoes; Springer: Berlin, Germany, 2014; pp. 87-345.

11. Fournier, T.; Pritchard, M.; Riddick, S. Duration, magnitude, and frequency of subaerial volcano deformation events: New results from Latin America using InSAR and a global synthesis. Geochem. Geophys. Geosyst. 2010, 11. [CrossRef]

12. Pritchard, M.E.; Simons, M. An InSAR-based survey of volcanic deformation in the southern Andes. Geophys. Res. Lett. 2004, 31. [CrossRef]

13. Biggs, J.; Ebmeier, S.; Aspinall, W.; Lu, Z.; Pritchard, M.; Sparks, R.; Mather, T. Global link between deformation and volcanic eruption quantified by satellite imagery. Nat. Commun. 2014, 5. [CrossRef] [PubMed] 
14. Ebmeier, S.; Biggs, J.; Mather, T.; Amelung, F. On the lack of InSAR observations of magmatic deformation at Central American volcanoes. J. Geophys. Res. Solid Earth 2013, 118, 2571-2585. [CrossRef]

15. Hensley, S.; Wheeler, K.; Sadowy, G.; Miller, T.; Shaffer, S.; Muellerschoen, R.; Jones, C.; Zebker, H.; Madsen, S.; Rosen, P. Status of a UAVSAR designed for repeat pass interferometry for deformation measurements. In Proceedings of the 2005 IEEE MTT-S International Conference on Microwave Symposium Digest, Long Beach, CA, USA, 12-17 June 2005.

16. Eggers, A.A. The Geology and Petrology of the Amatitlán Quadrangle, Guatemala; Dartmouth College: Hanover, NH, USA, 1971.

17. Conway, F.M.; Diehl, J.F.; Matías, O. Paleomagnetic constraints on eruption patterns at the Pacaya composite volcano, Guatemala. Bull. Volcanol. 1992, 55, 25-32. [CrossRef]

18. Kitamura, S.; Matías, O. Tephra stratigraphic approach to the eruptive history of Pacaya volcano, Guatemala. Sci. Rep. Tohoku Univ. Seventh Ser. Geogr. 1995, 45, 1-41.

19. Vallance, J.W.; Siebert, L.; Rose, W.I.; Girón, J.R.; Banks, N.G. Edifice collapse and related hazards in Guatemala. J. Volcanol. Geotherm. Res. 1995, 66, 337-355. [CrossRef]

20. Matías Gómez, R.O.; Rose, W.I.; Palma, J.L.; Escobar-Wolf, R. Notes on a Map of the 1961-2010 Eruptions of Volcán de Pacaya, Guatemala. Geol. Soc. Am. Digit. Map Chart Ser. 2012, 10. [CrossRef]

21. Rose, W.I.; Palma, J.L.; Wolf, R.E.; Gomez, R.O.M. A 50 year eruption of a basaltic composite cone: Pacaya, Guatemala. Geol. Soc. Am. Spec. Pap. 2013, 498, 1-21.

22. Schaefer, L.; Lu, Z.; Oommen, T. Dramatic volcanic instability revealed by InSAR. Geology 2015, 43, 743-746. [CrossRef]

23. Schaefer, L.N.; Oommen, T.; Corazzato, C.; Tibaldi, A.; Escobar-Wolf, R.; Rose, W.I. An integrated field-numerical approach to assess slope stability hazards at volcanoes: the example of Pacaya, Guatemala. Bull. Volcanol. 2013, 75, 1-18. [CrossRef]

24. CONRED. Coordinadora Nacional Para la Reduccion de Desastres. Available online: http:/ / www.conred.gob.gt/ (accessed on 1 October 2015).

25. Massonnet, D.; Feigl, K.L. Radar interferometry and its application to changes in the Earth's surface. Rev. Geophys. 1998, 36, 441-500. [CrossRef]

26. Rosen, P.; Hensley, S.; Joughin, I.R.; Li, F.K.; Madsen, S.N.; Rodriguez, E.; Goldstein, R.M. Synthetic aperture radar interferometry. Proc. IEEE 2000, 88, 333-382. [CrossRef]

27. Costantini, M. A novel phase unwrapping method based on network programming. IEEE Trans. Geosci. Remote Sens. 1998, 36, 813-821. [CrossRef]

28. Lu, Z.; Masterlark, T.; Dzurisin, D. Interferometric synthetic aperture radar study of Okmok volcano, Alaska, 1992-2003: Magma supply dynamics and postemplacement lava flow deformation. J. Geophys. Res. Solid Earth (1978-2012) 2005, 110. [CrossRef]

29. Sigmundsson, F.; Durand, P.; Massonnet, D. Opening of an eruptive fissure and seaward displacement at Piton de la Fournaise volcano measured by RADARSAT satellite radar interferometry. Geophys. Res. Lett. 1999, 26, 533-536. [CrossRef]

30. Wallace, P.J. Volatiles in subduction zone magmas: concentrations and fluxes based on melt inclusion and volcanic gas data. J. Volcanol. Geotherm. Res. 2005, 140, 217-240. [CrossRef]

31. Shinohara, H. Excess degassing from volcanoes and its role on eruptive and intrusive activity. Rev. Geophys. 2008, 46. [CrossRef]

32. Andres, R.; Rose, W.; Stoiber, R.; Williams, S.; Matías, O.; Morales, R. A summary of sulfur dioxide emission rate measuremnts from Guatemalan volcanoes. Bull. Volcanol. 1993, 55, 379-388. [CrossRef]

33. Rodríguez, L.A.; Watson, I.M.; Rose, W.I.; Branan, Y.K.; Bluth, G.J.; Chigna, G.; Matías, O.; Escobar, D.; Carn, S.A.; Fischer, T.P. $\mathrm{SO}_{2}$ emissions to the atmosphere from active volcanoes in Guatemala and El Salvador, 1999-2002. J. Volcanol. Geotherm. Res. 2004, 138, 325-344. [CrossRef]

34. Walker, J.A.; Roggensack, K.; Patino, L.C.; Cameron, B.I.; Matías, O. The water and trace element contents of melt inclusions across an active subduction zone. Contrib. Mineral. Petrol 2003, 146, 62-77. [CrossRef]

35. Eggers, A.A. Temporal gravity and elevation changes at Pacaya volcano, Guatemala. J. Volcanol. Geotherm. Res. 1983, 19, 223-237. [CrossRef]

36. Masterlark, T.; Lu, Z.; Rykhus, R. Thickness distribution of a cooling pyroclastic flow deposit on Augustine Volcano, Alaska: Optimization using InSAR, FEMs, and an adaptive mesh algorithm. J. Volcanol. Geotherm. Res. 2006, 150, 186-201. [CrossRef] 
37. Ebmeier, S.; Biggs, J.; Mather, T.; Wadge, G.; Amelung, F. Steady downslope movement on the western flank of Arenal volcano, Costa Rica. Geochem. Geophys. Geosyst. 2010, 11. [CrossRef]

38. Briole, P.; Massonnet, D.; Delacourt, C. Post-eruptive deformation associated with the 1986-87 and 1989 lava flows of Etna detected by radar interferometry. Geophys. Res. Lett. 1997, 24, 37-40. [CrossRef]

39. Caricchi, L.; Biggs, J.; Annen, C.; Ebmeier, S. The influence of cooling, crystallisation and re-melting on the interpretation of geodetic signals in volcanic systems. Earth Planet. Sci. Lett. 2014, 388, 166-174. [CrossRef]

40. Lu, Z.; Fielding, E.; Patrick, M.R.; Trautwein, C.M. Estimating lava volume by precision combination of multiple baseline spaceborne and airborne interferometric synthetic aperture radar: The 1997 eruption of Okmok volcano, Alaska. IEEE Trans. Geosci. Remote Sens. 2003, 41, 1428-1436.

41. Dietterich, H.R.; Poland, M.P.; Schmidt, D.A.; Cashman, K.V.; Sherrod, D.R.; Espinosa, A.T. Tracking lava flow emplacement on the east rift zone of Kìlauea, Hawai'i, with synthetic aperture radar coherence. Geochem. Geophys. Geosyst. 2012, 13. [CrossRef]

42. Lu, Z.; Dzurisin, D.; Biggs, J.; Wicks, C.; McNutt, S. Ground surface deformation patterns, magma supply, and magma storage at Okmok volcano, Alaska, from InSAR analysis: 1. Intereruption deformation, 1997-2008. J. Geophys. Res. Solid Earth (1978-2012) 2010, 115. [CrossRef]

43. Ebmeier, S.; Biggs, J.; Mather, T.; Elliott, J.; Wadge, G.; Amelung, F. Measuring large topographic change with InSAR: Lava thicknesses, extrusion rate and subsidence rate at Santiaguito volcano, Guatemala. Earth Planet. Sci. Lett. 2012, 335, 216-225. [CrossRef]

44. Gudmundsson, A. How local stresses control magma-chamber ruptures, dyke injections, and eruptions in composite volcanoes. Earth Sci. Rev. 2006, 79, 1-31. [CrossRef]

45. Schaefer, L.N.; Kendrick, J.E.; Lavallée, Y.; Oommen, T.; Chigna, G. Geomechanical rock properties of a basaltic volcano. Front. Earth Sci. 2015, 3. [CrossRef]

46. Salzer, J.T.; Nikkhoo, M.; Walter, T.R.; Sudhaus, H.; Reyes-Dávila, G.; Bretón, M.; Arámbula, R. Satellite radar data reveal short-term pre-explosive displacements and a complex conduit system at Volcán de Colima, Mexico. Front. Earth Sci. 2014, 2. [CrossRef]

47. Morgan, H.A.; Harris, A.J.; Gurioli, L. Lava discharge rate estimates from thermal infrared satellite data for Pacaya Volcano during 2004-2010. J. Volcanol. Geotherm. Res. 2013, 264, 1-11. [CrossRef]

(C) 2016 by the authors; licensee MDPI, Basel, Switzerland. This article is an open access article distributed under the terms and conditions of the Creative Commons by Attribution (CC-BY) license (http://creativecommons.org/licenses/by/4.0/). 